\title{
Direct Reprogramming of Somatic Cells to Neurons: Pros and Cons of Chemical Approach
}

\author{
Cristiana Mollinari ${ }^{1,2} \cdot$ Daniela Merlo ${ }^{2}$
}

Received: 17 December 2020 / Revised: 31 January 2021 / Accepted: 20 February 2021 / Published online: 5 March 2021

(c) The Author(s) 2021

\begin{abstract}
Translating successful preclinical research in neurodegenerative diseases into clinical practice has been difficult. The preclinical disease models used for testing new drugs not always appear predictive of the effects of the agents in the human disease state. Human induced pluripotent stem cells, obtained by reprogramming of adult somatic cells, represent a powerful system to study the molecular mechanisms of the disease onset and pathogenesis. However, these cells require a long time to differentiate into functional neural cells and the resetting of epigenetic information during reprogramming, might miss the information imparted by age. On the contrary, the direct conversion of somatic cells to neuronal cells is much faster and more efficient, it is safer for cell therapy and allows to preserve the signatures of donors' age. Direct reprogramming can be induced by lineage-specific transcription factors or chemical cocktails and represents a powerful tool for modeling neurological diseases and for regenerative medicine. In this Commentary we present and discuss strength and weakness of several strategies for the direct cellular reprogramming from somatic cells to generate human brain cells which maintain age-related features. In particular, we describe and discuss chemical strategy for cellular reprogramming as it represents a valuable tool for many applications such as aged brain modeling, drug screening and personalized medicine.
\end{abstract}

\section{Commentary}

Adult cells are believed to maintain their differentiated status under stable homeostatic conditions, while cellular identity can become plastic when homeostasis is perturbed such as during an injury and inflammation [1]. Indeed, it is now evident that cell identity is more flexible and plastic than previously thought. In particular, recent studies have shown that it is possible to influence cell fate through artificial manipulation such as exogenous expression of a set of transcription factors (TFs) that results in the reprogramming of adult skin fibroblasts to a pluripotent state [2]. In addition, recent reports have demonstrated that one type of differentiated somatic cell can be directly reprogrammed to another type of cell, without rejuvenation to a pluripotent state, in a process called transdifferentiation [3, 4]. Transdifferentiation is an epigenetic acquisition by a cell of a given type of the

Cristiana Mollinari

cristiana.mollinari@ift.cnr.it

1 Institute of Translational Pharmacology, National Research Council, Via Fosso del Cavaliere 100, 00133 Rome, Italy

2 Department of Neuroscience, Istituto Superiore di Sanita', Viale Regina Elena 299, 00161 Rome, Italy properties and features of another cell type, loosing its own phenotype [5].

Adult brain has very limited regeneration capability, thus, the possibility of a direct neuronal reprogramming from nonneuronal cells, bypassing a pluripotent state, would induce the formation of precious neuronal cells. This direct cellular generation thus represents a potential remedy for neuronal loss caused by brain injuries or neurodegeneration. In addition, the direct conversion of patient-specific cells could be used to implement disease-relevant in vitro platforms to generate models for neurodegenerative diseases, identify targets, and screen potential therapeutic drugs. Indeed, 100s of millions of people worldwide are affected by neurological disorders, making them one of the greatest threats to public health.

This Commentary discusses current knowledge on direct reprogramming towards neuronal cell identity, and more specifically, recent advances in transdifferentiation mediated by the exclusive use of chemical cocktails, remarking advantages and limits. To our opinion, direct reprogramming approaches represent an innovative strategy to overcome major barrier of the inaccessibility of human brain to obtain human neurons for studies of pathological mechanisms of diseases (Fig. 1). Moreover, directly converted induced 
Fig. 1 Advantages and disadvantages of direct reprogramming using different exogenous factors

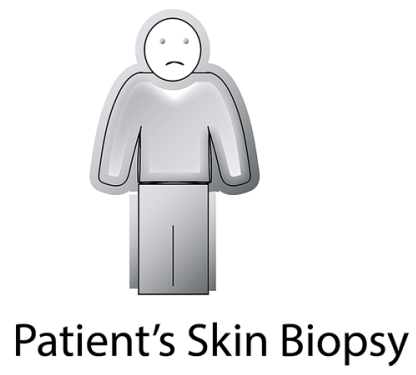

Direct Reprogramming

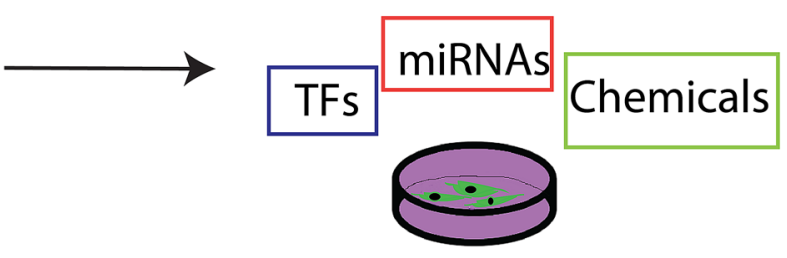

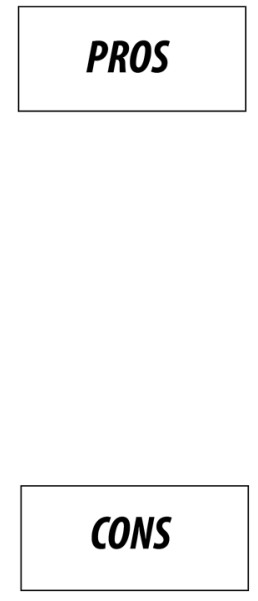

neurons (iNs) from human donor-derived fibroblasts possess important features of cellular aging, including global transcriptomic changes, nuclear pore defects, and DNA methylation, rendering them a valuable tool for the study of age-related neurological diseases [3, 6-8]. The importance of age preservation for disease modeling was recently illustrated also in Hungtington's disease where aggregation of the disease-causing mutant Huntingtin protein can be recapitulated in directly converted striatal neurons but not in neurons derived-iPSC, probably linked to the erasure of age signatures [9].

Among the various strategies to obtain direct reprogramming, ectopic expression of TFs in non-neuronal cells has generated neurons and neural progenitors both in vitro and in vivo [10-26]. Direct conversion by TFs stands on their ability to bind to inaccessible neuronal genes in differentiated non-neuronal cell types which are generally called as pioneer TFs (Fig. 1).
-Rapid protocols to generate neurons

-Age memory maintainance

-Autologous cell trasplantation

-Direct and indirect in vivo application

-Personalized medicine

-No ethical concerns

\section{-Cell survival and integration}

in brain circuitry in vivo remains

unexplored

-Difficult to develop standardized

protocols

-Health concerns (use of viral vectors)

The first direct conversion strategy was achieved by the overexpression of the three TFs, namely Ascl1, Brn2, and Myt11 (BAM factors), in mouse fibroblasts [27], and was then extended to BAM with NeuroD1 to convert human fibroblasts to iNs with a similar efficacy [28]. Recently, it has been suggested that a huge variety of TF combinations can be applied to generate subtype-specific iNs from fibroblasts (Table 1) and TF screening studies for iN conversion have led to the identification of additional pro-neuronal factors, such as Brn3a/b/c, Brn4s, and Ezh2 [29, 30]. Particularly interesting appear the recent advances in direct neuronal reprogramming in various defects linked to genetic alterations and ageing such as diabetic retinopathies, glaucoma, and macular degeneration that cause the death of retinal neurons and profound vision loss [31]. Indeed, Lu et al. present evidence that the ectopic expression of OCT4, SOX2 and KLF4 (OSK) TFs safely restores in vivo youthful DNA methylation patterns and transcriptomes of aged retinal 
Table 1 A summary of recent in vitro strategies discussed in this Commentary for direct reprogramming, focusing on chemicals, using human cells

\begin{tabular}{|c|c|c|c|c|}
\hline Cell source & Direct conversion strategy & Type of neurons & Methods PROS/CONS & Citations \\
\hline \multirow[t]{6}{*}{ Fibroblasts } & BAM + LMX1a, FOXA2 & GLUT + DOPA & Viral vector, health concern & [10] \\
\hline & BAM + NEUROD1 & GLUT & Viral vector, health concern & [28] \\
\hline & ASCL1, NGN2 & GLUT, GABA, DOPA & $\begin{array}{l}\text { Viral vector and chemicals } \\
\text { High efficiency } \\
\text { Health concern }\end{array}$ & {$[3,8,11,12,53,57]$} \\
\hline & $\begin{array}{l}\text { Chemical cocktail Valporic } \\
\text { acid, Forskolin, Repsox, } \\
\text { CHIR99021, SP600125, } \\
\text { GO6983, Y-27632 }\end{array}$ & GLUT & $\begin{array}{l}\text { Only chemical compounds } \\
\text { Low efficiency, no health } \\
\text { concern }\end{array}$ & [49] \\
\hline & $\begin{array}{l}\text { miRNA 9/9*, miRNA } 124 \text { ISL1 } \\
\text { and LHX3 }\end{array}$ & Motor neurons & Viral vector, health concern & [35] \\
\hline & $\begin{array}{l}\text { miRNA 9/9*, miRNA } \\
\text { 124+ TFs (BCL11B, DLX1, } \\
\text { DLX2, and MYT1L) }\end{array}$ & Striatal medium spiny neurons & Viral vector, health concern & [36] \\
\hline Retinal Müller cells & OCT4, SOX2, KLF4 & $\begin{array}{l}\text { Retinal neurons with regenera- } \\
\text { tion abilitites and recovered } \\
\text { youthful epigenetic informa- } \\
\text { tion }\end{array}$ & Viral vector, health concern & [32] \\
\hline Blood cells & $\mathrm{BAM}+\mathrm{NGN} 2$ & GLUT, GABA & Viral vector, health concern & [13] \\
\hline Nasal olfactory cells & $\begin{array}{l}\text { Chemical and growth fac- } \\
\text { tor cocktail BDNF, GDNF, } \\
\text { ascorbic acid, cyclic } \\
\text { AMP, CHIR99021, NT3, } \\
\text { LDN-193189 Noggin, and } \\
\text { SB-431542 }\end{array}$ & DOPA & $\begin{array}{l}\text { Only chemical compounds } \\
\text { Not working on fibroblasts } \\
\text { No health concern, } \\
\text { Possible application in cell } \\
\text { transplants }\end{array}$ & {$[60]$} \\
\hline \multirow[t]{3}{*}{ Glia cells } & $\begin{array}{l}\text { Chemical cocktail LDN193189, } \\
\text { SB431542, TTNPB, Tzv, } \\
\text { CHIR99021, DAPT, VPA, } \\
\text { SAG, and Purmo }\end{array}$ & Mainly GLUT, few GABA & $\begin{array}{l}\text { Only chemical compounds } \\
\text { No health concern, } \\
\text { Works only with glia from brain } \\
\text { not spinal cord } \\
\text { Fetal human cells, ethical } \\
\text { concern }\end{array}$ & {$[50]$} \\
\hline & $\begin{array}{l}\text { Chemical cocktail VPA, } \\
\text { CHIR99021, Repsox, Forsko- } \\
\text { lin, i-Bet151, and ISX-9 }\end{array}$ & GLUT & $\begin{array}{l}\text { Only chemical compounds } \\
\text { No health concern, } \\
\text { Adult glia cells, no ethical } \\
\text { concern }\end{array}$ & [51] \\
\hline & $\begin{array}{l}\text { Chemical cocktail SB431542, } \\
\text { LDN193189, CHIR99021, } \\
\text { and DAPT }\end{array}$ & GLUT & $\begin{array}{l}\text { Only chemical compounds } \\
\text { No health concern } \\
\text { Fetal human cells, ethical } \\
\text { concern }\end{array}$ & [73] \\
\hline
\end{tabular}

ganglion cells and propose that epigenetic reprogramming, either by gene therapy or other means, may promote tissue repair and thus, may be a promising strategy for reverting age-related decline and aged-induced pathologies in humans [32].

More interestingly, TFs and endogenous genes vital to the transdifferentiation process can be specifically targeted and silenced or upregulated, using methods that focus on the direct manipulation of DNA or the epigenetic environment, such as CRISPR/Cas9 [33, 34]. Moreover, the ability to drive direct reprogramming is not limited to TFs, as non-coding RNAs can promote it as well $[35,36]$. In addition, the culture conditions, including increased time in culture and developing coculture with astrocytes, may have an impact in terms of both phenotypic fate and efficiency of reprogramming.

The use of viral vectors to introduce exogenous transgenes into cells is currently the most prominent method to induce transdifferentiation. Generally, lentiviruses and retroviruses are mostly used due to their ability to effectively integrate directly into the genome of the host cell and confer a proper level of TF expression. However, viral delivery of TFs possesses undesirable side effects, including possible mutations leading to oncogenesis, thus posing problems for possible clinical trial application. That is the reason why non-integrating vectors have been developed, although associated with lower efficiencies of transdifferentiation, including: certain serotypes of AAVs reported to successfully cross the 
blood-brain barrier, Sendai virus, plasmid vectors, minicircles, and mRNA vectors which remain in the cytoplasm where they are translated into proteins [37-39]. Alternative non-viral methods, such as transient transfection and electroporation (for retina [40, 41], for brain [42-44]) can also be applied. However, due to their low efficiency, transgene silencing, inflammation and poor nuclear uptake, are less commonly used in transdifferentiation studies [45]. Lately, the use of neural exosomes [46] and the protein transduction domains (PTDs) fused to TFs allow the direct delivery of exogenous TFs avoiding the problems associated with DNA integration into the host genome [47] opening up new strategies for possible clinical applications.

Besides TFs, small molecules, modulating specific targets and epigenetic mechanisms, have been used to produce neural progenitors [48] and neurons [49-51] in in vitro cultures (Fig. 1). Small molecules can be applied in combination with viral agent-mediated TF delivery to improve the reprogramming efficiency [52-57] although, chemical reprogramming alone can be easily administrated and converted into therapeutic intervention. In the last years, several groups have identified combinations of small molecules capable of transdifferentiating somatic cells such as fibroblasts, astrocytes and even glioblastoma cells into neurons [48-51, 54, 58] (Table 1). Small molecules can convert human astrocytes or fibroblasts into functional neurons (chemical induced Neurons, ciNs), with a yield of up to $85 \%$ neurons from fetal and adult astrocytes [50,51], which is lower from human fibroblasts, with an efficiency of no more than $15 \%$ [49]. For sure, fibroblasts are better starting cells for direct neuronal reprogramming because of easier access for acquisition than astrocytes, although their lower reprogramming efficiency to neurons needs to be increased for broader application in neurological diseases. For example, Yang et al. reported that human fibroblasts can be efficiently and directly reprogrammed into glutamatergic neurons by serially exposing cells to a combination of twelve small molecules [59]. These ciNs displayed neuronal transcriptional networks, and also exhibited mature firing patterns and formed functional synapses. Although many reports have demonstrated that small molecules can convert one type of terminally differentiated somatic cell to another fully differentiated cell type, there are still various major aspects ahead that must be overcome. Indeed, protocols using small molecules produce mainly glutamatergic subtypes with rare gabaergic and dopaminergic neurons (Table 1). The inability to produce the neuronal subtypes which are lost in neurodegenerative disorders like Parkinson's disease, Alzheimer's disease, Amyotrophic Lateral Sclerosis, Huntingdon's disease represents a major limitation in current small molecules transdifferentiation field. However, it was showed that a single TF such as ASCL1, using a novel protein intracellular delivery technology, in combination with the small molecules LDN193189, SB431542,
DAPT and valproic acid can rapidly reprogram astrocytes into mature GABAergic and glutamatergic interneurons with high efficiency [47]. Moreover, Chabrat et al. developed a novel in vitro model of dopaminergic-like neurons derived from human nasal olfactory stem cells through a six step transdifferentiation protocol based on a specific combination of signaling pathway modulators [60]. Indeed, chemical cocktails offer the possibility of fine-tuning their effects by altering their concentrations and combinations. Thus, it is reasonable to envisage that by performing screening assays with different small molecules combinations, for example exploiting microfluidic and chip technology, along with slight modifications of the chemical recipe, depending on the starting somatic cell, it would be possible to achieve higher efficiency and additional neuronal lineages.

The main disadvantages of transdifferentiation by chemical approach to generate brain cells with specific properties consist in a low efficiency, a mixed population of neurons with different degrees of maturity and a unique subtype of neurons, although capable to maintain the age-related features associated with the human pathology (Fig. 1). In this respect, it is noteworthy that generation of neurons by direct reprogramming with age and pathology memory, would be important for disease modeling and drug screening studies but would represent a limit for autologous cell transplantation due to the preservation of the pathological features.

Forced expression of exogenous TFs for the direct reprogramming is supposed to damage proper epigenetic marks and genome integrity, whereas chemical compound-based conversion should be milder, leading to a better conservation of the ageing conditions. Thus, we believe that the chemical strategy may represent a new valid method for generating cells for both basic research and clinical applications. It is important to consider that the rapid metabolic transition that takes place during the fate switch from somatic cell to neuron puts enormous stress on the cell, leading to the formation of reactive oxygen species (ROS), known to induce toxicity and affect cell fate regulation, representing a major barrier to transdifferentiation [61]. For this reason an intermediate stage of reprogramming would reduce this oxidative stress, promoting a safer transition between cell fates and improving efficiency [21]. In this respect, the generation of neural stem or progenitor cells (NPCs) from other somatic cells, can largely improve the efficiency of the protocol since each neural stem cell can produce several neurons.

Small molecules can also facilitate the approach of Cell Activation and Signaling-Directed (CASD) reprogramming, which leads cells into an epigenetically activated transition state (cell activation) that, in conjunction with lineage-specific signals (signaling-directed), reprograms somatic cells into NPCs [62-66]. In this respect, Zhu et al. demonstrated that a single gene, Oct 4 , in conjunction with a chemical cocktail containing CHIR99021, A-83-01, 
$\mathrm{NaB}$, LPA, rolipram, and SP600125 was sufficient to convert human fibroblasts into expandable NPCs [67].

The most exciting perspective of direct reprogramming is the possibility that it might be achievable in patients in vivo [68-70]. Performing in vivo transdifferentiation would eliminate the need for cell transplantation and immunosuppression depending on the target application. However, potential adverse effects of direct reprogramming in vivo could include inappropriate differentiation into other cell types or even tumor cells. In addition, induced cells could be dysfunctional and detrimental to the brain structure. On the other hand, implantation of patient-derived midbrain dopaminergic progenitor cells, differentiated in vitro from autologous iPSCs, was succesfull to stabilize/improve symptoms of PD without the need for immunosuppression [71].

In animal models, transdifferentiation in vivo is now currently feasible, revealing the important role of resident glial cells in the generation of specific neurons to restore lost neuronal circuitries. For example, reactive astrocytes and NG2 cells can be directly reprogrammed into functional neurons inside mouse brain with the expression of a single neural TF, NEUROD1 [19]. Other TFs, such as neurogenin 2 (NGN2), ASCL1, and SOX2, have also been reported to reprogram glial cells into neurons both in vitro and in vivo [72].

Unfortunately, so far, in vivo studies to induce chemical transdifferentiation accomplished only with small molecules resulted either in promoting only an increase in adult brain neurogenesis [73] or reprogramming of mouse astrocytes into scattered functional mature neurons with electrophysiological characteristics and integration with resident neurons in the brain [74]. In complex, current in vivo studies although appealing are still superficial and limited to confirm reprogrammed cell capabilities, cell survival and integration and a more extensive testing in animal models is necessary before finding a clinical application.

In conclusion, over the past years, several strategies for direct cellular reprogramming have been developed to generate brain cells with age-preserved features rendering them a valuable tool for many applications such as aged brain modeling and age-related diseases.

Although transdifferentiation methods, due to the low efficiency, are quite limited, there is ongoing research that aims at improving this limit specially with the advent of in situ transdifferentiation, and with the emergence of CRISPR/Cas9 system as an alternative to TF overexpression methods. In addition, although some disadvantages need to be overcome, transdifferentiation by chemical reprogramming remains an important tool not only in vitro for disease modeling, new biomarkers discovery and drug screening, but also for future possible application in regenerative medicine.
Open Access This article is licensed under a Creative Commons Attribution 4.0 International License, which permits use, sharing, adaptation, distribution and reproduction in any medium or format, as long as you give appropriate credit to the original author(s) and the source, provide a link to the Creative Commons licence, and indicate if changes were made. The images or other third party material in this article are included in the article's Creative Commons licence, unless indicated otherwise in a credit line to the material. If material is not included in the article's Creative Commons licence and your intended use is not permitted by statutory regulation or exceeds the permitted use, you will need to obtain permission directly from the copyright holder. To view a copy of this licence, visit http://creativecommons.org/licenses/by/4.0/.

\section{References}

1. Sanchez Alvarado A, Yamanaka S (2014) Rethinking differentiation: stem cells, regeneration, and plasticity. Cell 157:110-119

2. Takahashi K, Yamanaka S (2006) Induction of pluripotent stem cells from mouse embryonic and adult fibroblast cultures by defined factors. Cell 126:663-676

3. Mertens J, Paquola ACM, Ku M, Hatch E, Bohnke L, Ladjevardi S, McGrath S, Campbell B, Lee H, Herdy JR, Goncalves JT, Toda T, Kim Y, Winkler J, Yao J, Hetzer MW, Gage FH (2015) Directly reprogrammed human neurons retain aging-associated transcriptomic signatures and reveal age-related nucleocytoplasmic defects. Cell Stem Cell 17:705-718

4. Mollinari C, Zhao J, Lupacchini L, Garaci E, Merlo D, Pei G (2018) Transdifferentiation: a new promise for neurodegenerative diseases. Cell Death Dis 9:830

5. Graf T (2011) Historical origins of transdifferentiation and reprogramming. Cell Stem Cell 9:504-516

6. Huh CJ, Zhang B, Victor MB, Dahiya S, Batista LF, Horvath S, Yoo AS (2016) Maintenance of age in human neurons generated by microRNA-based neuronal conversion of fibroblasts. Elife 5:e18648

7. Tang Y, Liu ML, Zang T, Zhang CL (2017) Direct reprogramming rather than iPSC-based reprogramming maintains aging hallmarks in human motor neurons. Front Mol Neurosci 10:359

8. Kim Y, Zheng X, Ansari Z, Bunnell MC, Herdy JR, Traxler L, Lee H, Paquola ACM, Blithikioti C, Ku M, Schlachetzki JCM, Winkler J, Edenhofer F, Glass CK, Paucar AA, Jaeger BN, Pham S, Boyer L, Campbell BC, Hunter T, Mertens J, Gage FH (2018) Mitochondrial aging defects emerge in directly reprogrammed human neurons due to their metabolic profile. Cell Rep 23:2550-2558

9. Victor MB, Richner M, Olsen HE, Lee SW, Monteys AM, Ma C, Huh CJ, Zhang B, Davidson BL, Yang XW, Yoo AS (2020) Author correction: striatal neurons directly converted from Huntington's disease patient fibroblasts recapitulate age-associated disease phenotypes. Nat Neurosci 23:1307

10. Pfisterer U, Kirkeby A, Torper O, Wood J, Nelander J, Dufour A, Bjorklund A, Lindvall O, Jakobsson J, Parmar M (2011) Direct conversion of human fibroblasts to dopaminergic neurons. Proc Natl Acad Sci USA 108:10343-10348

11. Aydin B, Kakumanu A, Rossillo M, Moreno-Estelles M, Garipler G, Ringstad N, Flames N, Mahony S, Mazzoni EO (2019) Proneural factors Ascl1 and Neurog2 contribute to neuronal subtype identities by establishing distinct chromatin landscapes. Nat Neurosci 22:897-908

12. Chanda S, Ang CE, Davila J, Pak C, Mall M, Lee QY, Ahlenius H, Jung SW, Sudhof TC, Wernig M (2014) Generation of induced neuronal cells by the single reprogramming factor ASCL1. Stem Cell Rep 3:282-296 
13. Tanabe K, Ang CE, Chanda S, Olmos VH, Haag D, Levinson DF, Sudhof TC, Wernig M (2018) Transdifferentiation of human adult peripheral blood T cells into neurons. Proc Natl Acad Sci USA 115:6470-6475

14. Berninger B, Costa MR, Koch U, Schroeder T, Sutor B, Grothe B, Gotz M (2007) Functional properties of neurons derived from in vitro reprogrammed postnatal astroglia. J Neurosci $27: 8654-8664$

15. Heinrich C, Blum R, Gascon S, Masserdotti G, Tripathi P, Sanchez R, Tiedt S, Schroeder T, Gotz M, Berninger B (2010) Directing astroglia from the cerebral cortex into subtype specific functional neurons. PLoS Biol 8:e1000373

16. Grande A, Sumiyoshi K, Lopez-Juarez A, Howard J, Sakthivel B, Aronow B, Campbell K, Nakafuku M (2013) Environmental impact on direct neuronal reprogramming in vivo in the adult brain. Nat Commun 4:2373

17. Mazzoni EO, Mahony S, Closser M, Morrison CA, Nedelec S, Williams DJ, An D, Gifford DK, Wichterle H (2013) Synergistic binding of transcription factors to cell-specific enhancers programs motor neuron identity. Nat Neurosci 16:1219-1227

18. Torper O, Pfisterer U, Wolf DA, Pereira M, Lau S, Jakobsson J, Bjorklund A, Grealish S, Parmar M (2013) Generation of induced neurons via direct conversion in vivo. Proc Natl Acad Sci USA 110:7038-7043

19. Guo Z, Zhang L, Wu Z, Chen Y, Wang F, Chen G (2014) In vivo direct reprogramming of reactive glial cells into functional neurons after brain injury and in an Alzheimer's disease model. Cell Stem Cell 14:188-202

20. Liu ML, Zang T, Zhang CL (2016) Direct lineage reprogramming reveals disease-specific phenotypes of motor neurons from human ALS patients. Cell Rep 14:115-128

21. Gascon S, Murenu E, Masserdotti G, Ortega F, Russo GL, Petrik D, Deshpande A, Heinrich C, Karow M, Robertson SP, Schroeder T, Beckers J, Irmler M, Berndt C, Angeli JP, Conrad M, Berninger B, Gotz M (2016) Identification and successful negotiation of a metabolic checkpoint in direct neuronal reprogramming. Cell Stem Cell 18:396-409

22. Wang LL, Su Z, Tai W, Zou Y, Xu XM, Zhang CL (2016) The p53 pathway controls SOX2-mediated reprogramming in the adult mouse spinal cord. Cell Rep 17:891-903

23. Nishida A, Furukawa A, Koike C, Tano Y, Aizawa S, Matsuo I, Furukawa T (2003) Otx2 homeobox gene controls retinal photoreceptor cell fate and pineal gland development. Nat Neurosci 6:1255-1263

24. Jorstad NL, Wilken MS, Grimes WN, Wohl SG, VandenBosch LS, Yoshimatsu T, Wong RO, Rieke F, Reh TA (2017) Stimulation of functional neuronal regeneration from Muller glia in adult mice. Nature 548:103-107

25. Yao K, Qiu S, Wang YV, Park SJH, Mohns EJ, Mehta B, Liu X, Chang B, Zenisek D, Crair MC, Demb JB, Chen B (2018) Restoration of vision after de novo genesis of rod photoreceptors in mammalian retinas. Nature 560:484-488

26. Lee H, Lee HY, Lee BE, Gerovska D, Park SY, Zaehres H, Arauzo-Bravo MJ, Kim JI, Ha Y, Scholer HR, Kim JB (2020) Sequentially induced motor neurons from human fibroblasts facilitate locomotor recovery in a rodent spinal cord injury model. Elife 9:e52069

27. Vierbuchen T, Ostermeier A, Pang ZP, Kokubu Y, Sudhof TC, Wernig M (2010) Direct conversion of fibroblasts to functional neurons by defined factors. Nature 463:1035-1041

28. Pang ZP, Yang N, Vierbuchen T, Ostermeier A, Fuentes DR, Yang TQ, Citri A, Sebastiano V, Marro S, Sudhof TC, Wernig $M$ (2011) Induction of human neuronal cells by defined transcription factors. Nature 476:220-223

29. Tsunemoto R, Lee S, Szucs A, Chubukov P, Sokolova I, Blanchard JW, Eade KT, Bruggemann J, Wu C, Torkamani A, Sanna
PP, Baldwin KK (2018) Diverse reprogramming codes for neuronal identity. Nature 557:375-380

30. Traxler L, Edenhofer F, Mertens J (2019) Next-generation disease modeling with direct conversion: a new path to old neurons. FEBS Lett 593:3316-3337

31. Liou RH, Edwards TL, Martin KR, Wong RC (2020) Neuronal reprogramming for tissue repair and neuroregeneration. Int $\mathrm{J}$ Mol Sci 21:4273

32. Lu Y, Brommer B, Tian X, Krishnan A, Meer M, Wang C, Vera DL, Zeng Q, Yu D, Bonkowski MS, Yang JH, Zhou S, Hoffmann EM, Karg MM, Schultz MB, Kane AE, Davidsohn N, Korobkina E, Chwalek K, Rajman LA, Church GM, Hochedlinger K, Gladyshev VN, Horvath S, Levine ME, Gregory-Ksander MS, Ksander BR, He Z, Sinclair DA (2020) Reprogramming to recover youthful epigenetic information and restore vision. Nature 588:124-129

33. Chakraborty S, Ji H, Kabadi AM, Gersbach CA, Christoforou N, Leong KW (2014) A CRISPR/Cas9-based system for reprogramming cell lineage specification. Stem Cell Rep 3:940-947

34. Chavez A, Scheiman J, Vora S, Pruitt BW, Tuttle M, Iyer EP, Lin S, Kiani S, Guzman CD, Wiegand DJ, Ter-Ovanesyan D, Braff JL, Davidsohn N, Housden BE, Perrimon N, Weiss R, Aach J, Collins JJ, Church GM (2015) Highly efficient Cas9-mediated transcriptional programming. Nat Methods 12:326-328

35. Abernathy DG, Kim KS, McCoy MJ, Lake AM, Ouwenga R, Lee SW, Xing X, Li D, Lee HJ, Heuckeroth RO, Dougherty JD, Wang T, Yoo AS (2017) MicroRNAs induce a permissive chromatin environment that enables neuronal subtype-specific reprogramming of adult human fibroblasts. Cell Stem Cell 21(3):332-348

36. Victor MB, Richner M, Hermanstyne TO, Ransdell JL, Sobieski C, Deng PY, Klyachko VA, Nerbonne JM, Yoo AS (2014) Generation of human striatal neurons by microRNA-dependent direct conversion of fibroblasts. Neuron 84:311-323

37. Larouche J, Aguilar CA (2019) New technologies to enhance in vivo reprogramming for regenerative medicine. Trends Biotechnol 37:604-617

38. Grath A, Dai G (2019) Direct cell reprogramming for tissue engineering and regenerative medicine. J Biol Eng 13:14

39. Pereira M, Birtele M, Rylander Ottosson D (2019) Direct reprogramming into interneurons: potential for brain repair. Cell Mol Life Sci 76:3953-3967

40. Matsuda T, Cepko CL (2004) Electroporation and RNA interference in the rodent retina in vivo and in vitro. Proc Natl Acad Sci USA 101:16-22

41. Lirong X, Danian C, Naihong Y (2014) In vivo electroporation of newborn mouse retina. Yi Chuan 36:1173-1178

42. Inoue T, Krumlauf R (2001) An impulse to the brain-using in vivo electroporation. Nat Neurosci 4(Suppl):1156-1158

43. De Vry J, Martinez-Martinez P, Losen M, Bode GH, Temel Y, Steckler T, Steinbusch HW, De Baets M, Prickaerts J (2010) Low current-driven micro-electroporation allows efficient in vivo delivery of nonviral DNA into the adult mouse brain. Mol Ther 18:1183-1191

44. Nomura T, Nishimura Y, Gotoh H, Ono K (2016) Rapid and efficient gene delivery into the adult mouse brain via focal electroporation. Sci Rep 6:29817

45. Gantenbein B, Tang S, Guerrero J, Higuita-Castro N, SalazarPuerta AI, Croft AS, Gazdhar A, Purmessur D (2020) Non-viral gene delivery methods for bone and joints. Front Bioeng Biotechnol 8:598466

46. Valerio LSA, Sugaya K (2020) Xeno- and transgene-free reprogramming of mesenchymal stem cells toward the cells expressing neural markers using exosome treatments. PLoS ONE 15:e0240469

47. Robinson M, Fraser I, McKee E, Scheck K, Chang L, Willerth SM (2018) Transdifferentiating astrocytes into neurons using ASCL1 
functionalized with a novel intracellular protein delivery technology. Front Bioeng Biotechnol 6:173

48. Cheng L, Hu W, Qiu B, Zhao J, Yu Y, Guan W, Wang M, Yang W, Pei G (2014) Generation of neural progenitor cells by chemical cocktails and hypoxia. Cell Res 24:665-679

49. Hu W, Qiu B, Guan W, Wang Q, Wang M, Li W, Gao L, Shen L, Huang Y, Xie G, Zhao H, Jin Y, Tang B, Yu Y, Zhao J, Pei G (2015) Direct conversion of normal and Alzheimer's disease human fibroblasts into neuronal cells by small molecules. Cell Stem Cell 17:204-212

50. Zhang L, Yin JC, Yeh H, Ma NX, Lee G, Chen XA, Wang Y, Lin L, Chen L, Jin P, Wu GY, Chen G (2015) Small molecules efficiently reprogram human astroglial cells into functional neurons. Cell Stem Cell 17:735-747

51. Gao L, Guan W, Wang M, Wang H, Yu J, Liu Q, Qiu B, Yu Y, Ping Y, Bian X, Shen L, Pei G (2017) Direct generation of human neuronal cells from adult astrocytes by small molecules. Stem Cell Rep 8:538-547

52. Chambers SM, Fasano CA, Papapetrou EP, Tomishima M, Sadelain M, Studer L (2009) Highly efficient neural conversion of human ES and iPS cells by dual inhibition of SMAD signaling. Nat Biotechnol 27:275-280

53. Ladewig J, Mertens J, Kesavan J, Doerr J, Poppe D, Glaue F, Herms S, Wernet P, Kogler G, Muller FJ, Koch P, Brustle O (2012) Small molecules enable highly efficient neuronal conversion of human fibroblasts. Nat Methods 9:575-578

54. Li X, Zuo X, Jing J, Ma Y, Wang J, Liu D, Zhu J, Du X, Xiong L, Du Y, Xu J, Xiao X, Wang J, Chai Z, Zhao Y, Deng H (2015) Small-molecule-driven direct reprogramming of mouse fibroblasts into functional neurons. Cell Stem Cell 17:195-203

55. Pfisterer U, Ek F, Lang S, Soneji S, Olsson R, Parmar M (2016) Small molecules increase direct neural conversion of human fibroblasts. Sci Rep 6:38290

56. Qi Y, Zhang XJ, Renier N, Wu Z, Atkin T, Sun Z, Ozair MZ, Tchieu J, Zimmer B, Fattahi F, Ganat Y, Azevedo R, Zeltner N, Brivanlou AH, Karayiorgou M, Gogos J, Tomishima M, TessierLavigne M, Shi SH, Studer L (2017) Combined small-molecule inhibition accelerates the derivation of functional cortical neurons from human pluripotent stem cells. Nat Biotechnol 35:154-163

57. Herdy J, Schafer S, Kim Y, Ansari Z, Zangwill D, Ku M, Paquola A, Lee H, Mertens J, Gage FH (2019) Chemical modulation of transcriptionally enriched signaling pathways to optimize the conversion of fibroblasts into neurons. Elife 8:e41356

58. Lee C, Robinson M, Willerth SM (2018) Direct reprogramming of glioblastoma cells into neurons using small molecules. ACS Chem Neurosci 9:3175-3185

59. Yang Y, Chen R, Wu X, Zhao Y, Fan Y, Xiao Z, Han J, Sun L, Wang X, Dai J (2019) Rapid and efficient conversion of human fibroblasts into functional neurons by small molecules. Stem Cell Rep 13:862-876

60. Chabrat A, Lacassagne E, Billiras R, Landron S, Pontisso-Mahout A, Darville H, Dupront A, Coge F, Schenker E, Piwnica D, Nivet E, Feron F, Mannoury la Cour C (2019) Pharmacological transdifferentiation of human nasal olfactory stem cells into dopaminergic neurons. Stem Cells Int 2019:2945435

61. Lu J, Li Y, Mollinari C, Garaci E, Merlo D, Pei G (2019) Amyloid-beta Oligomers-induced mitochondrial DNA repair impairment contributes to altered human neural stem cell differentiation. Curr Alzheimer Res 16:934-949
62. Corti S, Nizzardo M, Simone C, Falcone M, Donadoni C, Salani S, Rizzo F, Nardini M, Riboldi G, Magri F, Zanetta C, Faravelli I, Bresolin N, Comi GP (2012) Direct reprogramming of human astrocytes into neural stem cells and neurons. Exp Cell Res 318:1528-1541

63. Kim J, Efe JA, Zhu S, Talantova M, Yuan X, Wang S, Lipton SA, Zhang K, Ding S (2011) Direct reprogramming of mouse fibroblasts to neural progenitors. Proc Natl Acad Sci USA 108:7838-7843

64. Thier M, Munst B, Mielke S, Edenhofer F (2012) Cellular reprogramming employing recombinant sox 2 protein. Stem Cells Int 2012:549846

65. Wang L, Wang L, Huang W, Su H, Xue Y, Su Z, Liao B, Wang H, Bao X, Qin D, He J, Wu W, So KF, Pan G, Pei D (2013) Generation of integration-free neural progenitor cells from cells in human urine. Nat Methods 10:84-89

66. Lee JH, Mitchell RR, McNicol JD, Shapovalova Z, Laronde S, Tanasijevic B, Milsom C, Casado F, Fiebig-Comyn A, Collins TJ, Singh KK, Bhatia M (2015) Single transcription factor conversion of human blood fate to NPCs with CNS and PNS developmental capacity. Cell Rep 11:1367-1376

67. Zhu S, Ambasudhan R, Sun W, Kim HJ, Talantova M, Wang X, Zhang M, Zhang Y, Laurent T, Parker J, Kim HS, Zaremba JD, Saleem S, Sanz-Blasco S, Masliah E, McKercher SR, Cho YS, Lipton SA, Kim J, Ding S (2014) Small molecules enable OCT4mediated direct reprogramming into expandable human neural stem cells. Cell Res 24:126-129

68. Srivastava D, DeWitt N (2016) In vivo cellular reprogramming: the next generation. Cell 166:1386-1396

69. Torper O, Gotz M (2017) Brain repair from intrinsic cell sources: turning reactive glia into neurons. Prog Brain Res 230:69-97

70. Li H, Chen $\mathrm{G}$ (2016) In vivo reprogramming for CNS repair: regenerating neurons from endogenous glial cells. Neuron $91: 728-738$

71. Schweitzer JS, Song B, Herrington TM, Park TY, Lee N, Ko S, Jeon J, Cha Y, Kim K, Li Q, Henchcliffe C, Kaplitt M, Neff C, Rapalino O, Seo H, Lee IH, Kim J, Kim T, Petsko GA, Ritz J, Cohen BM, Kong SW, Leblanc P, Carter BS, Kim KS (2020) Personalized iPSC-derived dopamine progenitor cells for Parkinson's disease. N Engl J Med 382:1926-1932

72. Torper O, Ottosson DR, Pereira M, Lau S, Cardoso T, Grealish S, Parmar M (2015) In vivo reprogramming of striatal NG2 glia into functional neurons that integrate into local host circuitry. Cell Rep $12: 474-481$

73. Yin JC, Zhang L, Ma NX, Wang Y, Lee G, Hou XY, Lei ZF, Zhang FY, Dong FP, Wu GY, Chen G (2019) Chemical conversion of human fetal astrocytes into neurons through modulation of multiple signaling pathways. Stem Cell Rep 12:488-501

74. Ma YXH, Du X, Wang L, Jin X, Sun S, Han Y, Han Y, Xu J, Huang Z, Chai Z, Deng H (2018) In vivo chemical reprogramming of astrocytes into functional neurons. BioRxiv 2018:305185

Publisher's Note Springer Nature remains neutral with regard to jurisdictional claims in published maps and institutional affiliations. 